\title{
TIPOLOGI PARTISIPASI POLITIK PEMILIH LAKI-LAKI DI KABUPATEN BOGOR BERDASARKAN PENGGUNAAN SUMBER INFORMASI POLITIK
}

\author{
Roni Jayawinangun, Dini Valdiani \\ winangun.roni@gmail.com \\ Fakultas lmu Sosial dan Ilmu Budaya, Universitas Pakuan
}

\section{Article Info}

Keyword:

Political information; male voters; typology of voters

\begin{abstract}
In nowdays context, the community political participation has slightly changed as a result of technological development. In 2018, our regional election had failed to achieve minum target of political participation level that had been given by the Indonesian government. The government was targeting 77.5 percent but in the reality the society participation level only reached 73.24 percent due to the low level of participation from male voters. This research is conducted in order to identify male voters typology in Bogor Regency based on their utilization of political information sources or media. Quantitative method was used as metodological approach, 200 male voters were taken as research sampel by using quota samping based on their electoral district, and Chi-Square Automatic Interaction Detector (CHAID) was used as data analysis. This research finds that television and internet are the most frequently used media meanwhile, campaign props and television are the most trusted source of political information. The typology of male voters with the highest percentage in Bogor Regency is apathetic voters (34\%) followed by naive (29.5\%), alienated (19\%) and loyal voters (17.5\%).
\end{abstract}

Copyright (C) 2020 Interaksi: Jurnal Ilmu Komunikasi. All rights reserved.

\section{PENDAHULUAN}

Kemajuan teknologi informasi dan penyiaran media massa yang meluas telah memberikan kontribusi untuk meningkatkan kebutuhan informasi. Keterbukaan informasi dan komunikasi dari berbagai sumber media massa termasuk internet secara tidak langsung meningkatkan pula kesadaran masyarakat peduli kepada masalah politik. Masyarakat tidak lagi takut untuk mengkritisi kebijakan pemerintah yang tidak pro rakyat, baik lewat media massa \& elektronik, LSM, kampus maupun organisasi kemasyarakatan. Tentunya perubahan iklim demokrasi ini diharapkan dapat bertahap (tidak terkontrol) dan berujung pada kesejahteraan rakyat Indonesia (Setiadi, 2009). Masalah politik tidak dapat dilepaskan dari pemilihan umum (Pemilu), karena Pemilu merupakan salah satu pilar demokrasi untuk menyelaraskan kebijakan pemerintah serta pembangunan berdasarkan kehendak rakyat sebagai pemilik kedaulatan.
Disahkannya Undang-undang No. 32 Tahun 2004 telah mengubah tata cara pemilihan kepala daerah. Kepala daerah yang sebelumnya dipilih oleh Dewan Perwakilan Rakyat Daerah (DPRD) diubah menjadi dipilih langsung oleh masyarakat. Dengan demikian kepala daerah yang masa jabatannya berakhir pada tahun 2005 dan setelahnya akan dipilih secara langsung oleh rakyat dalam suatu pemilihan langsung yang diselenggarakan oleh Komisi Pemilihan Umum (KPU).

KPU selaku instansi penyelenggara Pemilu dalam penyebarluasan informasi pemilu dalam bentuk kampanye dilakukan melalui sosialisasi, publikasi, dan pendidikan pemilih. Dari kampanye dapat membuat masyarakat melibatkan diri dalam kegiatan politik, seperti yang dikemukakan Milbrath bahwa seseorang akan merasa peka dan melibatkan diri dalam kegiatan politik apabila telah mempunyai sikap, persepsi, minat, dan pemahaman yang cukup mengenai politik (Miaz, 2012). 
Permasalahan politik yang masih menjadi kendala bagi pemerintah yaitu terkait partisipasi politik. Partisipasi politik menunjukan keterlibatan warga dalam segala tahapan kebijakan, mulai dari pembuatan keputusan sampai dengan penilaian keputusan, termasuk peluang untuk ikut serta dalam pelaksanaan keputusan. Permasalahan partisipasi politik terlihat pada pemilihan serentak pada Tahun 2018, berdasarkan data KPU tingkat partisipasi pada Pemilihan Kepala Daerah Tahun 2018 tidak mencapai target dengan persentase sebesar 73,24 persen masih dibawah target yang ditetapkan yaitu sebesar 77,5 persen (Direktorat Jendral Otonomi Daerah, 2018).

Di balik fenomena tidak tercapainya target partisipasi politik pada pilkada serentak Tahun 2018, terdapat sesuatu yang menarik yaitu tingkat partisipasi politik laki-laki. Secara umum di Provinsi Jawa Barat tingkat partisipasi laki-laki lebih rendah dibandingkan partisipasi perempuan. Berdasarkan data KPU pada pilkada Gubernur Jawa Barat Tahun 2018, tingkat partisipasi perempuan sebesar 74,34 persen, lebih tinggi dibandingkan tingkat partisipasi laki-laki sebesar 66,30 persen (KPU, 2018). Rendahnya partisipasi politik pemilih laki-laki salah satunya terjadi di Kabupaten Bogor.

Kabupaten bogor adalah salah satu Kabupaten di Jawa Barat dengan jumlah pemilih terbanyak mencapai 3.294.825 pemilih. Besarnya jumlah pemilih ini merupakan alasan peneliti memilih Kabupaten Bogor sebagai tempat penelitian, disamping termasuk 10 besar Kabupaten dengan tingkat partisipasi terendah di Provinsi Jawa Barat dengan tingkat partisipasi sebesar 69,9 persen (KPU, 2108). Banyak factor yang dapat menyebabkan rendahnya partisipasi politik, salah satu penyebab rendahnya partisipasi politik ini ditenggarai karena kurangnya informasi politik yang diterima masyarakat (Limilia \& Fuady, 2016). Informasi politik penting mulai dari memberikan kesadaran dan pemahaman politik hingga menanamkan kepercayaan dan perilaku politik. Peran media massa tidak dapat dipisahkan dalam menyebarkan informasi politik, salah satunya adalah publikasi media baik dalam bentuk cetak, elektronik maupun media baru (internet). Oleh karena itu, penting untuk mengetahui sumber informasi politik dan penggunaan sumber informasi pemilih.
Berdasarkan pemaparan diatas, partisipasi politik dan sumber informasi politik menjadi hal yang menarik untuk dijadikan kajian mengingat hal ini adalah bentuk kontribusi warga negara dalam proses demokrasi. Hasil penelitian (Saldaña et al., 2015) menyebutkan salah satu faktor pendorong dalam partisipasi politik adalah penggunaan media. Selain itu, media juga mempunyai peran yang sangat besar dalam membangun citra kandidat. Media seperti televisi, radio, koran dan handphone merupakan sumber referensi utama politik bagi kelas menengah yang mengalami kesulitan menentukan calon, yang kemudian informasi dan propaganda sengaja diciptakan untuk para swing voter atau pemilih pemula yang tidak terbelenggu pada ideologi politik tertentu (Madrah \& Mubarok, 2018). Begitu pentingnya peran sumber informasi politik dan kaitannya dengan partisipasi politik, maka dalam artikel ini akan dilihat penggunaan sumber informasi pemilih pemula dan akan diklasifikasikan berdasarkan tipologi menurut ketertarikan politik dan kepercayaan terhadap institusi.

\section{KAJIAN PUSTAKA}

\section{Metodologi}

Penelitian ini dilakukan di enam daerah pemilihan (dapil) Kabupaten Bogor yang meliputi 40 Kecamatan yaitu Dapil 1 yang terdiri dari lima Kecamatan, Dapil 2 terdiri dari enam Kecamatan, Dapil 3 terdiri dari 7 Kecamatan, Dapil 4 terdiri dari enam Kecamatan, Dapil 5 terdiri dari Sembilan Kecamatan dan Dapil 6 terdiri dari 7 tujuh Kecamatan. Waktu penelitian dilaksanakan selama enam bulan dari April sampai September 2019.

Penelitian ini menggunakan pendekatan kuantitatif untuk menjelaskan bagaimana karakteristik, preferensi dan perilaku pemilih laki-laki di Kabupaten Bogor serta untuk mengelompokan pemilih kedalam tipologi pemilih.

Data yang digunakan dalam penelitian ini adalah data primer dan data sekunder. Data primer diperoleh dari pengisian kuesioner dan wawancara singkat oleh responden dengan syarat sudah memiliki hak pilih sesuai aturan yang berlaku yaitu Warga Negara Indonesia dengan usia terendah 17 tahun atau sudah kawin, dan terdaftar sebagai pemilih di Kabupaten Bogor. Data primer digunakan untuk mengetahui penggunaan sum- 
ber informasi politik pemilih.

Populasi dari penelitian ini adalah total pemilih laki-laki yang terdaftar di KPUD Kabupaten Bogor pada Pilkada Serentak Tahun 2018 sebanyak 1.688.275 orang.

Data sekunder yang akan digunakan dari dokumen dari instansi seperti Komisi Pemilihan Umum (KPU), Badan Pusat Statistik (BPS) dan hasil penelitian yang relevan. Instrumen adalah alat bantu yang digunakan pada penelitian ini adalah kuesioner yang merupakan susunan pertanyaan/pernyataan yang akan diwawancarai langsung responden. Dasar jawaban responden adalah pertanyaan yang diajukan atau alternatif jawaban yang sudah tersedia dalam kuesioner.

Metode pengumpulan data menggunakan quota sampling berdasarkan wilayah Daerah Pemilihan. Penentuan jumlah responden menggunakan rumus slovin dengan tingkat error sebesar 7,5 persen maka didapatkan jumlah sampel minimal sebanyak 178 responden dan ditambahkan menjadi 200 responden.

\begin{tabular}{|c|c|c|c|}
\hline Dapil & $\Sigma$ Pemilih & $\begin{array}{c}\text { Persentase } \\
(\%)\end{array}$ & $\begin{array}{c}\Sigma \text { Sampel } \\
\text { (orang) }\end{array}$ \\
\hline BOGOR 1 & 293.711 & 17,4 & 35 \\
\hline BOGOR 2 & 280.451 & 16,6 & 33 \\
\hline BOGOR 3 & 256.197 & 15,2 & 30 \\
\hline BOGOR 4 & 264.887 & 15,7 & 31 \\
\hline BOGOR 5 & 318.648 & 18,9 & 38 \\
\hline BOGOR 6 & 274.381 & 16,3 & 33 \\
\hline Total & 1.688 .275 & 100 & 200 \\
\hline
\end{tabular}

Tabel 1. Jumlah dan Pembagian Sampel per Wilayah

\section{Sumber: KPU Kabupaten Bogor, 2018}

Data yang dikumpulkan dalam penelitian ini dianalisis dengan prosedur sebagai berikut:

\section{Analisis deskriptif}

Analisis deskriptif digunakan untuk menggambarkan sesuatu yang tengah berlangsung pada saat riset dilakukan dan memeriksa sebab-sebab dari suatu keadaan atau gejala tertentu. Analisis deskriptif ini digunakan dalam menggambarkan karakteristik responden, dan penggunaan saluran informasi

\section{Analisis Chi-square Automatic Interaction Detector} (CHAID).
Analisis CHAID digunakan untuk melakukan segmentasi. Analisis ini digunakan untuk membuat tipologi pemilih berdasarkan ketertarikan politik dan kepercayaan terhadap insitusi politik. Adapun yang menjadi variabel dependen adalah tipologi pemilih (naif, apatis, teralienasi dan setia) dan variabel dependennya adalah penggunaan sumber informasi politik (media social, televisi, radio, alat peraga kampanye)

\section{Kajian Konseptual}

\section{Sumber - Sumber Informasi}

Menurut Severin dan Tankard Teori informasi bersifat heuristik, dalam arti ia membimbing kita menuju fakta dan metode baru dan tidak dikenali sebelumnya. Teori informasi cukup umum untuk mengorganisir material jumlah yang besar, yang sebagian besar bersifat strategis atau penting bagi periset komunikasi (Severin \& Tankard, 2010). Informasi merupakan sistem yang terintegrasi dari hasil pengolahan stimulus dengan pengetahuan untuk dapat dimengerti manusia. Meskipun tidak semua informasi dapat dikomunikasikan menjadi pesan, namun transfer informasi memiliki peran penting dalam penelitian komunikasi politik di mana masyarakat memperoleh informasi dari berbagai sumber baik media massa, media sosial (new media) maupun media antarpribadi yang berasal dari komunikasi tatap muka secara langsung (komunikasi antarpribadi). Dalam hubungannya dengan informasi politik yang dapat diterima oleh khalayak tentang berbagai hal yang berkaitan dengan pemilu, sumber informasi memiliki peran penting. Sumber informasi yang berasal dari media massa dan media sosial menyebarkan informasi secara massif dan cepat. Sementara, sumber informasi interpersonal mengandalkan komunikasi antarpribadi, meskipun kecepatan jangkauannya lebih lambat namun kekuatan informasi yang disampaikan pada komunikasi antarpribadi jauh lebih kuat. Banyak fakta mengungkapkan bahwa informasi interpersonal lebih memiliki pengaruh yang lebih kuat pada masyarakat umum terutama pada isu-isu tertentu yang membuat masyarakat menjadi terancam (Martha, 2015, p. 11)

Media komunikasi dapat dikategorikan dalam dua bagian, yakni media umum dan media massa. Media umum ialah media yang dapat digunakan oleh segala 
bentuk komunikasi, contoh telepon, handphone, OHP, LCD proyektor, dan sebagainya. Media massa antara lain televisi, radio, internet, majalah, koran, tabloid, buku dan film (film bioskop dan bukan negatif film yang dihasilkan kamera) (Nurudin, 2017, p. 5).

Partisipasi Politik

Partisipasi politik menurut McClosky adalah kegiatan-kegiatan sukarela dari warga masyarakat melalui mana mereka mengambil bagian dalam proses pemilihan penguasaan dan secara langsung atau tidak langsung, dalam proses pembentukan kebijakan umum. Menurut Huntington dan Nelson "Partisipasi politik adalah kegiatan warga Negara yang bertindak sebagai pribadi-pribadi yang dimaksud untuk mengambil keputusan oleh pemerintah. Partisipasi bisa bersifat individual atau kolektif, teroganisir atau spontan, secara damai atau kekerasan, legal atau tidak legal, dan efektif atau tidak efektif (Budiardjo, 1994, pp. 183-184)

Penyelenggaraan pilpres 2014 berpedoman pada tahapan, program dan jadwal sebagaimana diatur dalam peraturan KPU. Peraturan KPU Nomor 4 Tahun 2014 tentang Tahapan Pilpres Pasal 4 dibagi ke dalam tiga proses yaitu tahapan persiapan, pelaksanaan dan penyelesaian. Sejalan dengan Samuel P. Huntington dan Joan Nelson yang membagi salah satu bentuk partisipasi politik ke dalam kegiatan pemilihan, yaitu kegiatan pemberian suara dalam pemilihan umum, mencari dana partai, menjadi tim sukses, mencari dukungan bagi calon legislatif Indikator partisipasi politik menurut Martha dapat dilihat secara tahapan keseluruhan dimulai dari (a) keterlibatan dalam kampanye, (b) keterlibatan dalam memberikan suara dan (c) keikutsertaan mengawasi pemilu (Martha, 2015).

Tipologi Pemilih

Tipologi yang terkait dengan informasi dikemukakan oleh Seligson yang berpendapat bahwa kepemilikan informasi tidak selalu menunjukkan bahwa individu merasa dia dapat mempengaruhi keputusan pemerintah. Kepercayaan terhadap institusi politik dan efikasi yang menjadi dasar dalam penentuan tipologi pemilih. Kombinasi antara kepercayaan pada institusi politik dan efikasi politik menghasilkan empat jenis pemilih, yaitu: (Indikator, 2013, p. 6; Mierina, 2011, p. 76)
1. Pemilih yang setia, yaitu pemilih yang terlibat aktif secara politik, punya efikasi tinggi dan percaya terhadap institusi politik.

2. Pemilih yang teralienasi yaitu pemilih yang memiliki efikasi politik, mempunyai political interest tinggi tapi kepercayaan terhadap institusi politik tidak sesuai dengan yang diharapkan.

3. Pemilih yang naif, yaitu pemilih yang tidak terlibat aktif, tidak memiliki efikasi, tidak memiliki ketertarikan politik tapi percaya begitu saja terhadap institusi - institusi politik.

4. Pemilih yang apatis adalah pemilih yang mempunyai efikasi politik dan ketertarikan yang rendah serta memiliki rasa kepercayaan terhadap institusi politik yang rendah.

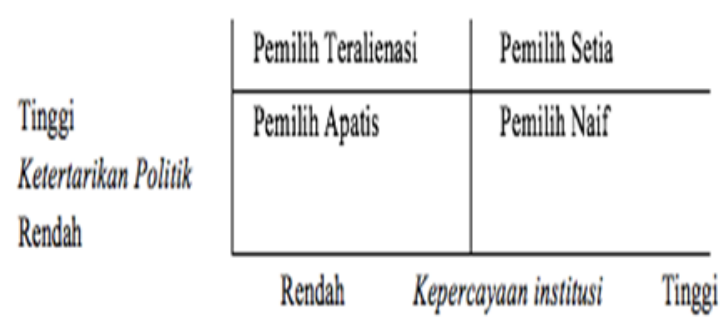

Gambar 1. Konfigurasi Pemilih

\section{TEMUAN DAN DISKUSI}

Penggunaan Sumber Informasi Politik Pemilih Laki-Laki di Kabupaten Bogor

Sumber informasi dalam konteks penelitian ini antara lain televisi, radio, majalah, koran, internet dan juga media sosial yang diakses dan digunakan dalam mencari informasi terkait berita dan perkembangan politik. Persentase penggunaan sumber informasi politik pemilih laki-laki di Kabupaten Bogor dapat dilihat pada Tabel 2 berikut.

\begin{tabular}{|l|c|c|c|}
\hline $\begin{array}{c}\text { Jenis } \\
\text { Media }\end{array}$ & $\begin{array}{c}\text { Pengguna } \\
\text { (\%) }\end{array}$ & $\begin{array}{c}\text { Frekuensi } \\
\text { (kali/hari) }\end{array}$ & $\begin{array}{c}\text { Durasi } \\
\text { (menit/ } \\
\text { hari) }\end{array}$ \\
\hline Televisi & 89,1 & $1-4$ & $15-30$ \\
\hline Koran & 5,7 & 1 & $10-20$ \\
\hline Radio & 3,4 & $1-2$ & $10-15$ \\
\hline Internet & 48,5 & $5-20$ & $5-30$ \\
\hline
\end{tabular}

Tabel 2. Penggunaan dan Sumber Informasi Politik Pemilih Laki-laki 
Berdasarkan Tabel 1, diketahui bahwa sumber informasi yang paling banyak diakses oleh pemilih lakilaki di Kabupaten adalah Televisi dengan persentase sebesar 89,1\% dengan durasi 15 - 30 menit dan frekuensi 1 - 4 kali per hari. Saluran yang paling banyak ditonton adalah RCTI, NET dan Indosiar. Pilihan saluran televisi ini dapat digunakan sebagai media penyebaran informasi politik baik dalam bentuk berita, maupun iklan. Televisi masih menjadi media utama bagi masyarakat Indonesia. Hal ini tercermin dari survei Nielsen Consumer Media View (CMV) yang menunjukkan bahwa penetrasi televisi mencapai 96 persen. Di urutan kedua media luar ruang dengan penetasi 53 persen, internet (44 persen), dan di posisi ketiga radio (37 persen) (AC Nielsen, 2017). Hal lain yang menjadikan televisi sebagai media utama adalah televisi merupakan sumber informasi yang dapat dipercaya dengan alasan jelas sumbernya, dapat dikonfirmasi dan adanya pengawasan pada sumber-sumber tersebut (Lestari, 2019, p. 10).

Media baru yaitu internet adalah jenis media kedua yang sering digunakan untuk mengakses informasi politik. Potensi internet dalam penyebaran informasi politik sangat besar, hal ini dikarenakan kemudahan dalam mengakses internet. Berdasarkan survey Nielsen Cross-Platform 2017, terjadi peningkatan akses internet di hampir semua tempat. Beberapa tempat di antaranya adalah Kendaraan Umum (53\%), Kafe atau Restoran (51\%), bahkan di acara konser (24\%). Selain itu semakin banyak juga orang yang melakukan dual-screen (menggunakan internet dan menonton televisi di waktu yang sama). Peningkatan konsumsi dualscreen yang rutin dilakukan setiap hari dapat ditemukan di semua kelompok usia. (AC Nielsen, 2017). Adapun situs internet yang biasa digunakan untuk mencari informasi politik adalah portal berita nasional, seperti detik.com dan kompas.com.

Dilihat dari kepercayaan pemilih laki-laki terkait informasi politik, maka diketahui bahwa forum tatap muka dengan caleg ataupun anggota partai dengan dialog merupakan media yang paling dipercaya, dikarenakan para pemilih dapat langsung berinteraksi dengan calon yang akan dipilihnya dalam pemilihan. Sumber informasi selanjutnya setelah tatap muka adalah baliho, berita acara di televisi, iklan di televisi dan internet. Berita di televisi mendapatkan porsi kepercayaan kurang dari $15 \%$ baik itu bentuk acara berita $(11,7 \%)$ maupun iklan partai $(10,3 \%)$, hal ini menunjukan bahwa televisi belum dapat mendorong pemilih pemula untuk menentukan pilihan politiknya namun sebatas menambah wawasan pemilih pemula (Kertayasa et al., 2017). Lebih jelas mengenai sumber informasi politik yang paling dipercaya dapat dilihat pada Gambar 2 .

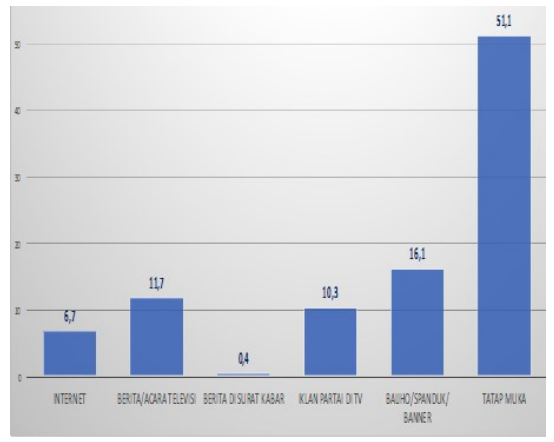

Gambar 2. Sumber Informasi Politik yang Paling Dipercaya

Tipologi Penggunaan Sumber Informasi politik dengan Partisipasi Politik laki-laki di Kabupaten Bogor

Partisipasi politik yang digunakan pada penelitian ini terdiri dari dua bagian yaitu kepercayaan terhadap institusi politik dan efikasi yang menghasilkan empat jenis pemilih, yaitu pemilih apatis, pemilih naif, pemilih terelinasi dan pemilih setia. Hasil tipologi pemilih Laki-laki di Kabupaten Bogor dapat dilihat pada Gambar 3 berikut.

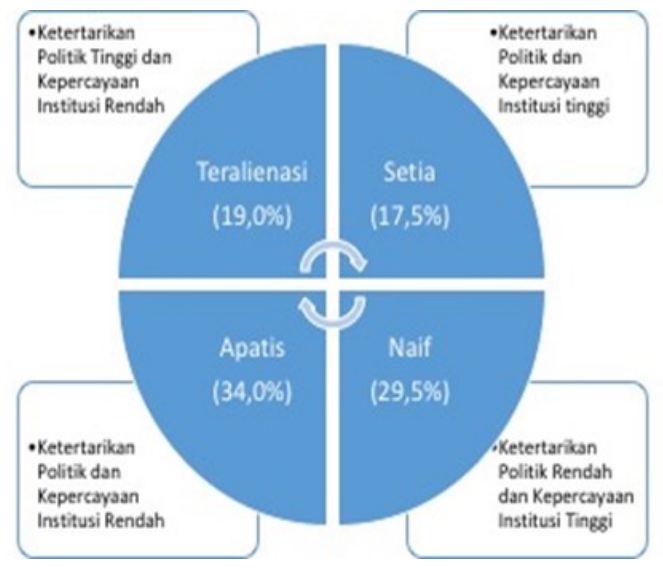

Gambar 3. Konfigurasi Tipologi Pemilih Laki-laki di Kabupaten Bogor 
Berdasarkan Gambar 3, diketahui bahwa persentase terbesar pemilih laki-laki di Kabupaten Bogor merupakan pemilih apatis dengan persentase $39,0 \%$, diikuti oleh pemilih naif sebesar $29,5 \%$, pemilih teralienasi sebesar $19,0 \%$ dan pemilih setia sebesar $17,5 \%$. Hal ini menunjukan masih banyak responden yang tidak tertarik politik dan memiliki kepercayaan yang rendah terhadap institusi politik (Indikator, 2013; Jayawinangun \& Nugroho, 2019). Jika dilihat berdasarkan kepercayaan terhadap institusi maka diketahui lebih banyak pemilih laki-laki yang kurang percaya kepada institusi politik sehingga mendorong ke dalam kelompok pemilih apatis dan teralienasi dengan persentase sebesar 53\%. Jika dilihat berdasarkan ketertarikan politik maka diketahui lebih banyak yang kurang tertarik dengan persentase sebesar $63,5 \%$.

Berdasarkan hasil analisis CHAID, diketahui bahwa tipologi dapat diklasifikasikan menjadi 5 (lima) kelompok berdasarkan sumber informasi politik. Dari lima sumber informasi yaitu televisi, koran, radio, media baru (internet dan media sosial) dan Alat Peraga Kampanye (baliho, spanduk, stiker, umbul-umbul, dan poster), hanya tiga sumber informasi politik penjelas yang berpengaruh terhadap tipologi pemilih yaitu APK, televisi dan media baru. Munculnya media baru dalam hal ini adalah media sosial dikarena media sosial sudah menjadi komoditi yang penting dalam pemilihan yang ditunjukan dengan banyak politisi yang membayar para buzzer media sosial, perusahaan pemantau media sosial, dan kemudian dikonsumsi dan diproduksi oleh pemilih, diorganisir dan dibentuk oleh pengusaha atau praktisi media sosial (Saraswati, 2018)

Berdasarkan hasil analisis CHAID diketahui bahwa pemilih dapat diklasifikasikan menjadi lima kelompok (Tabel 3).

\begin{tabular}{|c|c|c|}
\hline $\begin{array}{l}\text { Kla } \\
\text { sifi } \\
\text { kas } \\
\text { i }\end{array}$ & $\begin{array}{l}\text { No } \\
\text { de }\end{array}$ & Keterangan \\
\hline 1 & $\begin{array}{l}1 \\
\mathrm{da}\end{array}$ & $\begin{array}{l}\text { Setia, melihat informasi politik } \\
\text { dari media Alat Peraga Kampanye }\end{array}$ \\
\hline 2 & $\begin{array}{l}1 \\
4 \\
\text { da }\end{array}$ & $\begin{array}{l}\text { Alienasi, melihat informasi politik } \\
\text { dari media Alat Peraga Kampanye } \\
\text { (APK) dan media sosial }\end{array}$ \\
\hline 3 & $\begin{array}{l}1 \\
4 \\
\text { da }\end{array}$ & $\begin{array}{l}\text { Naif, melihat informasi politik dari } \\
\text { media Alat Peraga Kampanye } \\
\text { (APK) dan tidak melihat kampanye }\end{array}$ \\
\hline 4 & 2 & $\begin{array}{l}\text { Apatis, tidak melihat informasi } \\
\text { politik dari media Alat Peraga } \\
\text { Kampanye (APK) }\end{array}$ \\
\hline
\end{tabular}

Tabel 3. Pengklasifikasian berdasarkan diagram pohon CHAID

Hasil penelitian ini memiliki nilai estimasi sebesar 0.295 atau risiko sebesar 29,5\%, hal ini memiliki arti bahwa model akan salah memprediksi atau salah mengklasifikasi tipologi pemilih sebesar 29,5\% (Tabel 4).

\begin{tabular}{|c|c|}
\hline \multicolumn{2}{|l|}{ Risk } \\
\hline Std. Error & \\
\hline .035 & \\
\hline Growing Method: CHAID & \\
\hline Dependent Variable: tipol & \\
\hline
\end{tabular}

Tabel 4. Output Nilai Risk Analisis CHAID

Berdasarkan Tabel 3, dapat diketahui bahwa kelompok 1 adalah tipologi pemilih pemula yang setia yaitu pemilih yang tidak mengakses informasi politik melalui APK dan televisi. Hal tersebut menunjukan bahwa APK dan televisi adalah media yang dapat mendorong pemilih menjadi lebih setia, dikarenakan televisi dan APK merupakan media yang dipercaya dengan persentase terbesar kedua dan ketiga setelah tatap muka. Kedua sumber informasi politik ini dipercaya oleh pemilih laki-laki dikarenakan dibuat oleh pihakpihak yang dianggap kredibel oleh pemilih dan telah melalui proses yang sesuai aturan.

Kelompok 2 adalah kelompok pemilih pemula 
teralienasi yaitu pemilih yang mengakses informasi politik melalui APK dan dan Media Sosial. Media sosial dapat dengan cepat menyuguhkan berbagai informasi politik yang diinginkan mulai dari menampilkan figur calon, visi misi dan informasi lainnya yang dapat mendorong pemilih dalam menentukan pilihannya, namun disisi lain banyak juga informasi yang bertolak belakang yang menyebabkan masyarakat untuk skeptis terhadap politik seperti munculnya gerakan golongan putih (golput) oleh para netizen yang memberikan informasi mengenai golput yang merupakan kontra terhadap arah perjuangan demokrasi, selain itu maraknya bentuk - bentuk propaganda, dan praktik kampanye hitam yang kontra dengan nilai demokrasi (Madrah \& Mubarok, 2018).

Kelompok 3 adalah kelompok tipologi naif yaitu pemilih yang melihat APK namun tidak melihat informasi politik dari televisi dan media sosial. Kelompok naif ini pada dasarnya sudah memiliki pilihan, namun tidak aktif dalam mencari informasi. APK dianggap sebagai sumber informasi cukup yang meyakinkan bahwa eksistensi pilihannya sudah sesuai dengan kepentingan politik

Kelompok 4 adalah tipologi pemilih apatis, yaitu pemilih tidak melihat APK. Pada kelompok pemilih ini pada dasarnya tidak ada ketertarikan dalam mencari informasi politik, bahkan sumber informasi resmi pemerintah seperti APK. Kelompok apatis ini tidak peduli terhadap apapun informasi politik yang ada di sekitarnya.

Dari pengelompokan berdasarkan penggunaan media menunjukan bahwa semakin banyak sumber informasi politik yang digunakan dapat mendorong pemilih menjadi setia. Media yang digunakan dalam mencari informasi politik adalah APK, televisi dan media sosial, hal ini ditunjukan dari ketiga sumber informasi ini yang dapat membuat menjadi pemilih setia dan teralienasi. Sumber informasi yang dapat mendorong pemilih menjadi teralienasi salah satunya adalah media sosial.

Hal tersebut mendukung teori SR bahwa terpaan media yang menjadi stimulus memengaruhi tingkat partisipasi politik sebagai respon. Semakin banyak stimulus yang diberikan berupa informasi politik dari berbagai sumber maka akan semakin tinggi juga ketertarikan terhadap politik. Beberapa temuan penting juga telah didapatkan sesuai dengan konsep terpaan media dan partisipasi politik (Halim \& Jauhari, 2019; Kim \& Chen, 2016; Ognyanova \& Ball-Rokeach, 2015; Saldaña et al., 2015).

\section{KESIMPULAN}

Kesimpulan dari penelitian ini antara lain:

1) Penggunaan sumber informasi politik yang paling banyak digunakan oleh pemilih laki-laki di Kabupaten Bogor secara berurutan adalah televisi, media social, internet, koran/surat kabar dan radio. APK dan berita televisi adalah sumber informasi yang dipercaya pemilih laki-laki.

2) Tipologi pemilih Laki-laki di Kabupaten Bogor dari persentase yang paling besar adalah pemilih apatis diikuti oleh pemilih naif, pemilih teralienasi dan pemilih setia. Sumber informasi yang dapat meningkatkan ketertarikan politik adalah televisi, APK dan media sosial.

\section{REKOMENDASI}

Rekomendasi dari penelitian ini antara lain:

1. Institusi politik seperti KPU dan partai politik sebaiknya menggunakan sumber informasi interaktif dengan tanya jawab calon dapat secara langsung maupun dengan menggunakan media seperti televisi, internet, koran/surat kabar dan radio.

2. Lebih mengoptimalkan media baru seperti internet dan media sosial sebagai sarana penyebarluasan informasi yang interaktif terkait pemilihan umum secara berkala tidak hanya pada saat tahun pemilu agar pemilih lebih terdedah informasi dan dapat meningkatkan partisipasi politik sehingga dapat meningkatkan kepercayaan pemilih dan dapat mendorong pemilih apatis dan teralienasi menjadi pemilih setia ataupun naif.

3. Saran untuk penelitian selanjutnya adalah memperluas responden bukan hanya pada pemilih lakilaki tetapi pemilih tetap dan juga dapat diukur bagaimana pengaruh berdasarkan faktor demografi lainnya lokasi tempat tinggal (desa dan kota) 


\section{DAFTAR PUSTAKA}

AC Nielsen. (2017, July 26). Tren Baru Di Kalangan Pengguna Internet $\mathrm{Di}$ Indonesia [Press room]. www.nielson.com. https://www.nielsen.com/id/en/press -releases/2017/tren-baru-di-kalangan-pengguna-

internet-di-indonesia

Budiardjo, M. (1994). Demokrasi di Indonesia: Demokrasi parlementer dan demokrasi Pancasila : kumpulan karangan. Gramedia Pustaka Utama.

Direktorat Jendral Otonomi Daerah. (2018). Pilakada Serentak Tahun 2018 (p. 14). Kementerian Dalam Negeri. https://otda.kemendagri.go.id/wp-content/ uploads/2019/04/5.-Evaluasi-Pilkada-Serentak-

2018.pdf

Halim, U., \& Jauhari, K. D. (2019). Pengaruh Terpaan Media Terhadap Partisipasi Politik Dalam Pilkada DKI Jakarta 2017. Jurnal ASPIKOM, 4(1), 45. https:// doi.org/10.24329/aspikom.v4i1.385

Indikator. (2013). INTERNET, APATISME, DAN ALIENASI POLITIK Temuan Survei Nasional 19-27 Juni 2013 (p. 48) [Online]. Indikator Politik Indonesia. http://indikator.co.id/

up-

loads/20130723190925.23_Juli_2013_Rilis_INDIKAT OR.pdf

Jayawinangun, R., \& Nugroho, D. R. (2019). Segmentasi Pemilih Pemula Berdasarkan Akses Berita Politik Melalui Media Sosial Di Kabupaten Bogor. Jurnal Komunikasi Pembangunan, 17(2), 157-164.

Kertayasa, I. P. A. N., Gelgel, N. M. R. A., \& Pradipta, A. D. (2017). Analisis Terpaan Iklan Partai Politik Di Televisi Pada Pemilih Pemula Di Kota Denpasar Dalam Pemilu Legislatif 2014. E-Jurnal Medium, 1(1). https://ojs.unud.ac.id/index.php/komunikasi/article/ view/27635

Kim, Y., \& Chen, H.-T. (2016). Social media and online political participation: The mediating role of exposure to cross-cutting and like-minded perspectives. Telematics and Informatics, 33(2), 320-330. https:// doi.org/10.1016/j.tele.2015.08.008

Lestari, S. B. (2019). Pemaknaan Dan Sikap Remaja
Pada Berita Kampanye Pilpres 2019 Di Media Sosial. Interaksi: Jurnal Ilmu Komunikasi, 8(1), 1-11. https:// doi.org/10.14710/interaksi.8.1.1-11

Limilia, P., \& Fuady, I. (2016, October 11). Pencarian Informasi Topik Politik di Kalangan Pemilih Pemula (Studi Kasus Pola Pencarian Infomasi Politik Pada mahasiswa Fikom Unpad).

Madrah, M. Y., \& Mubarok, M. (2018). Netizen Dalam Kampanye PILPRES RI 2014. Interaksi: Jurnal Ilmu Komunikasi, 7(1), 16-25.

Martha, L. P. (2015). Hubungan Penggunaan Sumber Informasi Kampanye Dan Partisipasi Politik (Kasus Pilpres 2014 Di Kabupaten Bogor) [Thesis, Bogor Agricultural University (IPB)]. http://repository.ipb.ac.id/ xmlui/handle/123456789/80035

Miaz, Y. (2012). Partisipasi Politik: Pola Perilaku Pemilih pada Masa Orde Baru dan Reformasi. In S. R. Syahrul R. (Ed.), artisipasi Politik: Pola Perilaku Pemilih pada Masa Orde Baru dan Reformasi (pp. 1-203). UNP Press. http://repository.unp.ac.id/72/

Mierina, I. (2011). Political Participation and Development of Political Attitudes in Post-Communist Countries. University of Latvia.

Nurudin. (2017). Perkembangan Teknologi Komunikasi (2nd ed.). Raja Grafindo Persada.

Ognyanova, K., \& Ball-Rokeach, S. J. (2015). Political Efficacy on the Internet: A Media System Dependency Approach. In L. Robinson, S. R. Cotten, \& J. Schulz (Eds.), Studies in Media and Communications (Vol. 9, pp. 3-27). Emerald Group Publishing Limited. https:// doi.org/10.1108/S2050-206020150000009001

Saldaña, M., McGregor, S. C., \& Zuniga, H. G. D. (2015). Social Media as a Public Space for Politics: Cross-National Comparison of News Consumption and Participatory Behaviors in the United States and the United Kingdom. International Journal of Communication, 9, 3304-3326.

Saraswati, M. S. (2018). Social Media and the Political Campaign Industry in Indonesia. Jurnal Komunikasi Ikatan Sarjana Komunikasi Indonesia, 3(1), 51-65. https://doi.org/10.25008/jkiski.v3i1.124 
Setiadi, H. (2009). Menuju Demokrasi Dengan

Teknologi Informasi. semnasIF 2009, 4.

Severin, W. J., \& Tankard, J. W. (2010). Teori

Komunikasi: Sejarah, Metode, dan Terapan di Dalam

Media Massa -5/E. Kencana Prenada. https://

openlibrary.telkomuniversity.ac.id/pustaka/9749/teori-

komunikasi-sejarah-metode-dan-terapan-di-dalam-

media-massa-5-e-.html 